\section{Abdominal subcutaneous adipose tissue as a predictor of high-grade renal cell carcinoma} Villeda-Sandoval Chl, ${ }^{1}$ Calao-Pérez $M B,{ }^{1}$ Ugalde-Resano $R,{ }^{1}$ Chapa-lbargüengoi-
tia $M,{ }^{2}$ Castillejos-Molina RA, ${ }^{1}$ Del Moral-Ponce $S,{ }^{1}$ Rodríguez-Covarrubias $\mathrm{F}^{1}$

\section{Abstract}

BACKGROUND: information about the influence of abdominal adipose tissue on the prognosis and aggressiveness of renal cell carcinoma is scarce.

OBJECTIVE: to identify and quantify the relationship between abdominal adipose tissue and histopathologic characteristics of renal cell carcinoma.

MATERIALS AND METHODS: data on patients with renal cell carcinoma treated with partial or radical nephrectomy were retrospectively collected. Visceral adipose tissue and subcutaneous adipose tissue were measured on preoperative computerized tomography scans. Histopathologic (pathologic 2002 TNM classification, tumor size, nuclear grade, necrosis, and metastasis) and clinical (sex, age, body mass index) variables were assessed. Visceral adipose tissue and subcutaneous adipose tissue were adjusted by patient height (VAT-I and SAT-I). The association between adipose tissue measurements, patient characteristics, and histopathologic variables was assessed through a correlation, comparison, and regression analysis. A survival analysis was also carried out.

RESULTS: one-hundred and five patients were included. No significant relationship between visceral adipose tissue and histopathologic characteristics was found. SAT-I was a significant variable inversely related to sex, but more importantly to nuclear grade, $\mathrm{pN}+$, and necrosis. There was no influence of visceral adipose tissue or subcutaneous adipose tissue on survival.

CONCLUSIONS: subcutaneous adipose tissue was related to the histopathologic characteristics of renal cell carcinoma. A larger amount of subcutaneous adipose tissue predicted a low nuclear grade and a lower frequency of $\mathrm{pN}+$ and necrosis. Further study to clarify the interaction between adipose tissue and renal cell carcinoma biology is required.

KEY WORDS: renal cell carcinoma, subcutaneous-abdominal adipose tissue, prognosis

\footnotetext{
${ }^{1}$ Department of Urology.

${ }^{2}$ Department of Radiology ( $\mathrm{MCl}$ ).

Instituto Nacional de Ciencias Médicas y Nutrición Salvador Zubirán, Mexico City.
}

Received: December 2016

Accepted: March 2017

\section{Correspondence}

Francisco Rodríguez-Covarrubias, M.D.

frodriguez.covarrubias@gmail.com

This article should be cited as

Villeda-Sandoval Chl, Calao-Pérez MB, Ugalde-Resano R, Chapa-Ibargüengoitia M, Castillejos-Molina RA, Del Moral-Ponce S, Rodríguez-Covarrubias F. Abdominal subcutaneous adipose tissue as a predictor of high-grade renal cell carcinoma. Rev Mex Urol. 2017 mar;77(2):117-124. 


\section{Tejido adiposo abdominal subcutáneo como predictor de carcinoma renal de alto grado}

Villeda-Sandoval ChI, ${ }^{1}$ Calao-Pérez MB, ${ }^{1}$ Ugalde-Resano $\mathrm{R},{ }^{1}$ Chapa-Ibargüengoitia $\mathrm{M},{ }^{2}$ Castillejos-Molina RA, ${ }^{1}$ Del Moral-Ponce $\mathrm{S},{ }^{1}$ Rodríguez-Covarrubias $\mathrm{F}^{1}$

\section{Resumen}

ANTECEDENTE: la información acerca de la influencia del tejido adiposo abdominal en el pronóstico y agresividad del carcinoma de células reales es escasa.

OBJETIVO: identificar y cuantificar la relación entre tejido adiposo abdominal y las características histopatológicas del carcinoma de células reales.

MATERIALES Y MÉTODOS: estudio retrospectivo efectuado con base en datos de pacientes con carcinoma de células reales a quienes se realizó nefrectomía parcial o radical. El tejido adiposo visceral y subcutáneo se midieron con tomografía computada preoperatoria. Se evaluaron variables histopatológicas (TNM 2002, tamaño del tumor, grado nuclear, necrosis y metástasis) y clínicas (sexo, edad, índice de masa corporal). El tejido adiposo visceral y el subcutáneo se ajustaron para la altura de los pacientes (IVA-I y SAT-I). La asociación entre las mediciones del tejido adiposo, las características de los pacientes y las variables histopatológicas se evaluaron con un análisis de correlación, comparación y regresión. También se efectuó un análisis de supervivencia.

RESULTADOS: se estudiaron 105 pacientes y no se encontró relación significativa entre el tejido adiposo visceral y las características histopatológicas. SAT-I fue una variable significativa, inversamente relacionada con el sexo, pero destaca con el grado nuclear, $\mathrm{pN}+\mathrm{y}$ necrosis. No se observó influencia de tejido adiposo visceral o subcutáneo con la supervivencia

CONCLUSIONES: el tejido adiposo subcutáneo se relaciona con las características histopatológicas del carcinoma de células reales. El aumento de tejido adiposo subcutáneo predice un menor grado nuclear, menor frecuencia de $\mathrm{pN}+$ y necrosis. Se requiere de más estudios para clarificar la relación del tejido adiposo abdominal con la biología del carcinoma de células reales.

PALABRAS CLAVE: carcinoma de células renales, tejido adiposo abdominal-subcutáneo, pronóstico.

\author{
${ }^{1}$ Department of Urology. \\ ${ }^{2}$ Department of Radiology (MCl). \\ Instituto Nacional de Ciencias Médicas y \\ Nutrición Salvador Zubirán, Mexico City. \\ Correspondencia \\ Francisco Rodríguez-Covarrubias, M.D. \\ frodriguez.covarrubias@gmail.com
}

\section{INTRODUCTION}

Approximately 100,000 new cases of renal cell carcinoma are reported in the U.S. and Europe each year [1]. Several risk factors, such as smoking, hypertension, occupational exposure, and family history have been related to this disease [2]. Unfortunately, up to $30 \%$ of patients have 
metastasis at diagnosis [1]. Therefore, several attempts to identify risk factors of tumor aggressiveness have been pursued.

Since angiogenesis is a key factor in the development of renal cell carcinoma, molecular targeted therapy, including Vascular Endothelial Growth Factor inhibition, has become a standard of care for advanced renal cell carcinoma [3]. Adipogenesis and adipocytes are related to neovascularization of tumors, as they have common paracrine signaling pathways. [4]. Hence, theoretically, adipogenesis should be related to tumor angiogenesis.

Overweight and obesity are well known causes of adipocyte mass increase and they have been related to a higher incidence of renal cell carcinoma [5]. Moreover, adipose tissue mass is related to leptin and adiponectin, which modify malignant tumor angiogenesis [4]. Abdominal adipose tissue (AAT) has two components: Visceral adipose tissue (VAT) and subcutaneous adipose tissue (SAT) [6] for clinical assessment. An increase in total AAT has been related to a decrease in overall and progression-free survival in oncologic patients [7]. However, the information about its influence on the pathologic characteristics and aggressiveness of renal cell carcinoma is limited.

We have previously evaluated the reliability of computed tomography (CT) to predict nuclear grade in renal cell carcinoma [8]. In the present study we aimed to identify and quantify AAT and its compartments, as measured by $\mathrm{CT}$, and determine their influence on histopathologic characteristics and outcomes of renal cell carcinoma in patients treated with radical or partial nephrectomy at a single tertiary care referral center in Mexico.

\section{PATIENTS AND METHODS}

A retrospective review of 500 renal cell carcinoma patients was conducted, retrieving the information from our institutional database.
The study was approved by the hospital center's ethics committee and complied with the Declaration of Helsinki and its later amendments. Patients underwent either partial or radical nephrectomy and only those having a complete 4-phase preoperative multidetector (64-slice) contrast-enhanced abdominopelvic CT scan employing our institutional Picture Archiving and Communications System (PACS) were selected. These records have been electronically stored since 2005. Patients were further selected from the 2005 to 2013 period to carry out a minimum 2-year follow-up. Patients with no electronically stored CT scans were excluded from the review.

Clinical variables (age, sex, and body-mass index [BMI]) and histopathologic characteristics (2002 TNM stage, tumor size, nuclear grade, and tumor necrosis) were assessed. We searched for a relationship between these variables and AAT and surrogate amounts.

AAT was quantified using the non-contrasted CT scan with a previously validated method [6]. Two continuous axial slices at L4 or L5 were selected. Manual regions of interest were superposed over the images to include the SAT and VAT compartments. The area that included pixels in the -190 to $-30 \mathrm{HU}$ was measured by an expert radiologist (MCl) who was blinded to the histopathologic features. An average of the measurements for each compartment was calculated with a final measurement in square centimeters $(\mathrm{cm} 2)$.

Final adipose tissue variables were total adipose tissue (TAT), VAT, and SAT. AAT depends on each patient's idiosyncratic physical constitution. To correct the measurements for different patients' heights, indexes were created by dividing TAT, VAT, and SAT by height (in square meters), with a final result of square centimeters over square meters $(\mathrm{cm} 2 / \mathrm{m} 2)$. Final indexes were named TATI, VAT-I, and SAT-I. Visceral abdominal adipose tissue percentage (VAT\%) was included, as it has been previously described as a potentially related 
variable. It was obtained through the following formula: (VAT/TAT x 100)

An initial correlation analysis between the clinical and histopathologic variables with VAT, SAT, TAT, VAT\%, and the indexes was calculated using the Pearson and Spearman coefficients, as appropriate. Variables with a statistically significant correlation underwent regression analysis to measure a potential relationship with the histopathologic characteristics. Models were created to calculate the probability of a dichotomized nuclear grade as 1-2 vs. 3-4, a dichotomized $\mathrm{pN}$ as negative vs. positive, and tumor necrosis dichotomized as absent vs. present. Finally, the impact of different AAT areas and indexes on overall and cancer-specific survival was calculated using Kaplan Meier curves and the log-rank test. The calculations were made using the SPSS Statistics v. 21.0 (IBM Corp.) program. Statistical significance was stated as $p<0.05$.

\section{RESULTS}

One hundred ninety-four patients with renal cell carcinoma were operated on within the time frame of 2005 to 2013. Of these, 85 had no saved $\mathrm{CT}$ scan in the PACS and 4 were incomplete. Therefore, 105 patients were suitable for analysis. The baseline characteristics are shown in Table 1. Mean follow-up time was $20.8 \pm 19.1$ months (range 1-76, median: 16).

The initial exploratory correlation analysis is depicted in Table 2. SAT-I was selected as the candidate variable due to its significant and coherent relationship with the histopathologic characteristics of renal cell carcinoma. TAT-I was not selected because its significance was considered a surrogate of SAT-I.

No constant significant relationship was found between VAT, VAT-I, or VAT\% and the histopathologic characteristics.
Table 1. Baseline characteristics of the sample

\begin{tabular}{|c|c|c|}
\hline Total n (\%) & & $105(100)$ \\
\hline \multicolumn{3}{|l|}{ Demographics } \\
\hline Sex n $(\%)$ & $\begin{array}{c}\text { Female } \\
\text { Male }\end{array}$ & $\begin{array}{l}44(41.9) \\
61(58.1)\end{array}$ \\
\hline Age (years)* & & $58.1 \pm 13.1$ \\
\hline $\mathrm{BMI}(\mathrm{kg} / \mathrm{m})^{*}$ & & $27.0 \pm 5.1$ \\
\hline Height (meters)* & & $1.63 \pm 0.11$ \\
\hline TNM stage n(\%) & $\begin{array}{l}\text { I } \\
\text { II } \\
\text { III } \\
\text { IV }\end{array}$ & $\begin{array}{l}52(49.5) \\
15(14.3) \\
27(25.7) \\
11(10.5)\end{array}$ \\
\hline ECOG n(\%) & $\begin{array}{l}0 \\
1\end{array}$ & $\begin{array}{l}91(86.7) \\
14(13.3)\end{array}$ \\
\hline \multicolumn{3}{|l|}{ Tumor } \\
\hline Size $(\mathrm{cm})^{*}$ & & $7.0 \pm 4.7$ \\
\hline Nuclear grade n(\%) & $\begin{array}{c}1 \\
2 \\
3 \\
4 \\
\text { Unknown }\end{array}$ & $\begin{array}{c}8(7.6) \\
54(51.4) \\
22(21) \\
15(14.3) \\
6(5.7)\end{array}$ \\
\hline pT n(\%) & $\begin{array}{l}1 \\
2 \\
3 \\
4\end{array}$ & $\begin{array}{c}51(48.6) \\
16(15.2) \\
34(32.4) \\
4(3.8)\end{array}$ \\
\hline $\mathrm{pN}+\mathrm{n}(\%)$ & $\begin{array}{l}\text { PosNeg/ } \\
\text { Unknown }\end{array}$ & $\begin{array}{c}6(5.8) \\
99(94.2)\end{array}$ \\
\hline Metastasis n(\%) & $\begin{array}{l}\text { Pos Neg/ } \\
\text { Unknown }\end{array}$ & $\begin{array}{c}8(7.6) \\
97(92.4)\end{array}$ \\
\hline Necrosis $\mathrm{n}(\%)$ & $\begin{array}{l}\text { Pos Neg } \\
\text { Unknown }\end{array}$ & $\begin{array}{c}27(25.7) \\
64(61) \\
14(13.3)\end{array}$ \\
\hline \multicolumn{3}{|l|}{ Adipose Tissue } \\
\hline TAT $\left(\mathrm{cm}^{2}\right)^{*}$ & & $424.9 \pm 176.8$ \\
\hline SAT $\left(\mathrm{cm}^{2}\right)^{*}$ & & $267.3 \pm 128.4$ \\
\hline VAT $\left(\mathrm{cm}^{2}\right)^{*}$ & & $157.6 \pm 78.7$ \\
\hline TAT-I $\left(\mathrm{cm}^{2} / \mathrm{m}^{2}\right)^{*}$ & & $163.3 \pm 70.7$ \\
\hline SAT-I $\left(\mathrm{cm}^{2} / \mathrm{m}^{2}\right)^{*}$ & & $103.4 \pm 50.5$ \\
\hline VAT-I $\left(\mathrm{cm}^{2} / \mathrm{m}^{2}\right)^{*}$ & & $59.9 \pm 31.6$ \\
\hline VAT\%* & & $37.2 \pm 10.99$ \\
\hline
\end{tabular}

*average \pm standard deviation

TAT: Total abdominal adipose tissue, SAT: Subcutaneous abdominal adipose tissue, VAT: Visceral abdominal adipose tissue, TAT: Total abdominal adipose tissue index, SAT-I: Subcutaneous abdominal adipose tissue index, VAT-I: Visceral abdominal adipose tissue index, VAT\%: Visceral abdominal adipose tissue percentage, Pos: positive, Neg: negative 
Villeda-Sandoval Chl y col. Abdominal subcutaneous adipose tissue

Table 2. Significant Univariate Correlations (Coefficient, p)

\begin{tabular}{|c|c|c|c|c|c|c|c|}
\hline Variable & SAT & VAT & TAT & SAT-I & VAT-I & TAT-I & VAT $\%$ \\
\hline Sex & $0.37,<0.01$ & NS & NS & $0.51,<0.01$ & NS & $0.39,<0.01$ & $\begin{array}{l}-0.48 \\
<0.01\end{array}$ \\
\hline Age & NS & $0.26,0.01$ & NS & NS & $0.33,<0.01$ & NS & $0.31,<0.01$ \\
\hline BMI & $0.82,<0.01$ & $0.62,<0.01$ & $0.86,<0.01$ & $0.81,<0.01$ & $0.67,<0.01$ & $0.85,<0.01$ & NS \\
\hline Tumor size & NS & NS & NS & $-0.23,0.03$ & NS & $-0.21,0.04$ & NS \\
\hline $\begin{array}{l}\text { Nuclear } \\
\text { grade }\end{array}$ & $-0.24,0.01$ & NS & $-0.25,0.01$ & $-0.25,0.01$ & NS & $-0.25,0.01$ & NS \\
\hline TNM stage & $-0.19,0.04$ & NS & NS & NS & NS & NS & NS \\
\hline pT & $-0.21,0.03$ & NS & NS & $-0.20,0.04$ & NS & NS & NS \\
\hline $\mathrm{pN}+$ & $0.26,0.01$ & NS & $0.26,0.01$ & $0.25,0.01$ & $0.19,0.04$ & $0.28,0.01$ & NS \\
\hline Metastasis & NS & NS & NS & NS & NS & NS & NS \\
\hline Necrosis & $0.39,<0.01$ & $0.22,0.03$ & $0.37,<0.01$ & $0.33,0.01$ & NS & $0.30,0.01$ & NS \\
\hline
\end{tabular}

SAT: Subcutaneous abdominal adipose tissue, VAT: Visceral abdominal adipose tissue, TAT: Total abdominal adipose tissue, SAT-I: Subcutaneous abdominal adipose tissue index, VAT-I: Visceral abdominal adipose tissue index, TAT-I: Total abdominal adipose tissue index, VAT\%: Visceral abdominal adipose tissue percentage, NS: Non-significant, BMI: body mass index

A secondary comparative analysis was proposed. The median value for SAT-I $(96.9 \mathrm{~cm} 2 / \mathrm{m} 2)$ was selected to create two discriminatory groups for a group comparison. Group 1 included all subjects with a SAT-I $<96.9 \mathrm{~cm} 2 / \mathrm{m} 2$, and was compared with Group 2, composed of subjects with a SAT-I $\geq$ $96.9 \mathrm{~cm} 2 / \mathrm{m} 2$. The comparative analysis is shown in Table 3. Sex, nuclear grade, $\mathrm{pN}+$, and necrosis were significantly different between groups.

Finally, a univariate regression analysis was conducted using SAT-I as a continuous or dichotomic independent variable. The results are shown in Table 4. SAT-I is a significant predictor of sex, nuclear grade, $\mathrm{pN}+$, and necrosis.

SAT, VAT, TAT, SAT-I, VAT-I, TAT-I or VAT\% were not predictors of overall or cancer-specific survival.

\section{DISCUSSION}

Modifiable risk factors including BMI have been related to an increased incidence of renal
Table 3. Comparison between SAT-I groups $(<96.9)$ vs $(\geq 96.9) n=105$

\begin{tabular}{|c|c|c|c|c|}
\hline \multicolumn{2}{|c|}{ Variable $n(\%)$} & \multirow{2}{*}{$\begin{array}{c}\text { SAT-I }<96.9 \\
n=53\end{array}$} & \multirow{2}{*}{$\begin{array}{c}\text { SAT-I } \geq 96.9 \\
\quad n=52 \\
18(34.6) \\
34(65.4)\end{array}$} & \multirow{2}{*}{$\begin{array}{c}p \\
<0.01\end{array}$} \\
\hline Sex & $\begin{array}{c}\text { Male } \\
\text { Female }\end{array}$ & & & \\
\hline Age* & Years & $57.4 \pm 13.6$ & $58.2 \pm 12.7$ & 0.53 \\
\hline $\begin{array}{l}\text { Tumor } \\
\text { size* }\end{array}$ & $\begin{array}{l}\text { Centi- } \\
\text { meters }\end{array}$ & $7.8 \pm 5.7$ & $6.3 \pm 3.4$ & 0.19 \\
\hline $\begin{array}{l}\text { Nuclear } \\
\text { grade }\end{array}$ & $\begin{array}{c}1 / 2 \\
3 / 4 \\
\text { Unknown }\end{array}$ & $\begin{array}{c}26(49) \\
24(45.3) \\
3(5.7)\end{array}$ & $\begin{array}{c}36(69.2) \\
13(25) \\
3(5.8)\end{array}$ & 0.03 \\
\hline TNM stage & $\begin{array}{c}\text { I/II } \\
\text { III/IV }\end{array}$ & $\begin{array}{l}30(56.6) \\
23(43.4)\end{array}$ & $\begin{array}{l}37(71.2) \\
15(28.8)\end{array}$ & 0.05 \\
\hline pT & $\begin{array}{l}1 / 2 \\
3 / 4\end{array}$ & $\begin{array}{l}30(56.6) \\
23(43.4)\end{array}$ & $\begin{array}{l}37(71.2) \\
15(28.8)\end{array}$ & 0.07 \\
\hline $\mathrm{pN}$ & $\begin{array}{c}\text { Negative/ } \\
\text { Unknown } \\
\text { Positive }\end{array}$ & $\begin{array}{c}47(88.7) \\
6(11.3)\end{array}$ & $\begin{array}{c}52(100) \\
0(0)\end{array}$ & 0.01 \\
\hline Metastasis & $\begin{array}{l}\text { Negative/ } \\
\text { Unknown } \\
\text { Positive }\end{array}$ & $\begin{array}{c}47(88.7) \\
6(11.3)\end{array}$ & $\begin{array}{c}52(100) \\
0(0)\end{array}$ & 0.15 \\
\hline Necrosis & $\begin{array}{l}\text { Negative } \\
\text { Positive } \\
\text { Unknown }\end{array}$ & $\begin{array}{c}26(49.0) \\
20(37.8) \\
7(13.2)\end{array}$ & $\begin{array}{c}38(73.1) \\
7(13.5) \\
7(13.4)\end{array}$ & $<0.01$ \\
\hline
\end{tabular}


Table 4. Univariate regression analysis

\begin{tabular}{l|c|c|c|c|c|c|}
\hline & \multicolumn{3}{|c|}{$\begin{array}{c}\text { Independent variable: } \\
\text { SAT-I (continuous) }\end{array}$} & \multicolumn{3}{c|}{ Independent variable: } \\
SAT-I > 96.9
\end{tabular}

SAT-I: Subcutaneous abdominal adipose tissue index, HR: Hazard Ratio, CI: Confidence Interval, ref: reference

cancer carcinoma $[9,10]$ and up to $25 \%$ of the cases in the U.S. may be attributable to excess weight [11]. In addition, Chow et al. suggested that obesity may be related to more than $40 \%$ of renal cell carcinoma cases in a Swedish population [12]. Other studies have confirmed these findings $[7,13,14]$.

Calle et al. analyzed a U.S. cohort comprised of 900,000 participants and observed a direct relationship between high BMI and risk of mortality due to renal cell carcinoma [14]. Conversely, Steffens found that a BMI below normal was related to undifferentiated renal cell carcinoma tumors, microscopic vascular invasion, and metastatic disease [3]. Although a higher BMI is generally related to the incidence and mortality of renal cell carcinoma, other authors had contradictory results $[16,17,18]$, rendering $\mathrm{BMI}$ as an unreliable predictor.

The aim of this study was to find a relationship between AAT and its compartments with histopathologic characteristics of renal cell carcinoma. Our design could only find a transverse correlation between the variables at the time of diagnosis, thus inferences related to the incidence of renal cell carcinoma were not possible.

The way in which obesity relates to tumor aggressiveness is not yet well known. Theoretically, excess VAT creates a pro-inflammatory systemic environment that promotes tumor proliferation by decreasing or inhibiting apoptosis [18]. Cytokines, including "adipokines", as well as leptin and adiponectin, have been studied as possible modulators of renal cell carcinoma development $[17,18,19,20,21]$. Estrogen production, which is increased within adipose tissue, may also be involved in this phenomenon $[22,23]$.

An initial analysis of our study was previously presented with preliminary results. [24]. To the best of our knowledge, this is the first study suggesting a relationship between SAT and histopathologic characteristics of renal 
cell carcinoma. We found a significant relationship between SAT-I and histopathologic characteristics of renal cell carcinoma, such as nuclear grade, $\mathrm{pN}+$, and necrosis. Patients with a higher SAT content had a lower nuclear grade, a lower frequency of $\mathrm{pN}+$, and a lower frequency of necrosis in the histopathologic analysis, suggesting a protective role. A SAT-I $>96.9 \mathrm{~cm} 2 / \mathrm{m} 2$ conferred an HR of 2.556 of having a higher nuclear grade 3 or 4 , an HR of 8.696 of having $\mathrm{pN}+$, and an HR of 4.176 of having tumor necrosis.

A previous paper addressing the association of SAT and VAT with histopathologic characteristics of renal cell carcinoma was recently published [6]. The authors retrospectively reviewed 186 patients with cT1a renal cell carcinoma tumors. They found an association between increased visceral obesity and a higher Fuhrman grade. Unfortunately, their data are not directly comparable with ours since they evaluated patients with lower stages, whereas we included all stages of the disease. Furthermore, Zhu et al. analyzed VAT as a percentage of total AAT, and SAT was not independently studied. We addressed VAT and SAT as absolute values and as adjusted indexes because we consider both compartments to be independent. Moreover, we included an adjustment of AAT compartments with patient height, because the CT scan measurement technique only includes information from the abdominal area and constitutional body information is not taken into account. In our analysis, VAT had no significant results, even when adjusted as VAT-I. We believe that VAT and SAT must be studied independently, as they may reflect different patient characteristics: VAT is generally related to obesity and metabolic syndrome, whereas SAT may reflect nutritional status.

A second larger study was published by researchers from Korea [25] that included 706 patients with localized renal cell carcinoma, within the time frame of 2003 to 2012. They concluded that a higher VAT content measured as a percentage of TAT was directly related to an increased proportion of high-grade tumors. However, despite their stating that SAT was measured to calculate TAT, it was not included in the analysis.

Our research studied VAT and SAT as independent variables and VAT\% was included because it had been previously described. However, we only demonstrated a significant correlation with SAT. A potential explanation is that VAT has been previously studied as a percentage of TAT, which implicitly includes SAT. It would be interesting to analyze both compartments independently. Theoretically, a higher percentage of SAT would decrease the percentage of VAT and hence be concordant with our studies. We can infer that if a higher VAT content in previous papers were a risk for renal cell carcinoma aggressiveness, then a higher SAT content would be protective, thus confirming our theory.

The retrospective nature of our study and the relatively small sample size are among its drawbacks. Nevertheless, a strong relationship was found between SAT and histopathologic tumor characteristics. Our study population was heterogeneous and included localized and advanced stages of the disease, precluding direct comparisons with previous publications.

\section{CONCLUSION}

According to our analysis, subcutaneous adipose tissue is related to histopathologic characteristics of renal cell carcinoma. This study further supports a previously reported association of adipose tissue with renal cell carcinoma aggressiveness. It is suggested that adipose tissue may at least have a relationship with nuclear grade and the presence of necrosis. The interaction between adipose tissue compartments and renal cell 
carcinoma tumor biology is unknown, but as an endocrine organ, adipose tissue could modify renal cell carcinoma development.

\section{Conflict of interest}

The authors declare that there is no conflict of interest.

\section{Financial disclosure}

No financial support was received in relation to this study/article.

\section{REFERENCES}

1. Ladoire S, Bonnetain F, Gauthier M, et al. Visceral fat area as a new independent predictive factor of survival in patients with metastatic renal cell carcinoma treated with antiangiogenic agents. Oncologist 2011; 24: 71.

2. Dhôte R, Pellicer-Coeuret $M$, Thiounn N, et al. Risk factors for adult renal cell carcinoma: a systemic review and implications for prevention. BJU Int 2000; 86: 20.

3. Steffens $\mathrm{S}$, Grünwald V, Ringe KI, et al. Does obesity influence the prognosis of metastatic renal cell carcinoma in patients treated with endothelial growth factor-targeted therapy? Oncologist 2011; 16: 1565.

4. Cao Y. Angiogenesis modulates adipogenesis and obesity. J Clin Invest 2007; 117: 2362.

5. Lowrence WT, Thompson RH, Yee DS, et al. Obesity is associated with higher risk of clear-cell renal cell carcinoma than with other histologies. BJU Int 2010; 105: 16.

6. Zhu Y, Wang HK, Zhang HL, et al. Visceral Obesity and risk of high grade disease in clinical t1a renal cell carcinoma. J Urol 2013; 189: 447.

7. Renehan AG, Tyson M, Egger M, et al. Body-mass index and incidence of cancer: a systemic review and meta-analysis of prospective observational studies. Lancet 2008; 371: 569.

8. Villalobos-Gollás M, Aguilar-Davidov B, Culebro-García C, et al. Pathological implications of areas of lower enhancement on contrast-enhanced computed tomography in renal-cell carcinoma: additional information for selecting candidates for surveillance protocols. Int Urol Nephrol 2012; 44: 1369.

9. Purdue MP, Moore LE, Merino MJ, et al. An investigation of risk factor for renal cell carcinoma by histologic subtype in two case-control studies. Int J Cancer 2013; 132: 2640.
10. McGuire BB, Fitzpatrick JM. BMI and the risk of renal cell carcinoma. Curr Opin Urol 2011; 21: 356.

11. Beebe-Dimmer JL, Colt JS, Ruterbusch JJ, et al. Body mass index and renal cell cancer: the influence of race and sex. Epidemiology 2012; 23: 821.

12. Chow WH, Gridley G, Fraumeni JF Jr, et al. Obesity, hypertension, and the risk of kidney cancer in men. $\mathrm{N}$ Engl J Med 2000; 343: 1305.

13. Bergström A, Hsieh CC, Lindblad P, et al. Obesity and renal cell cancer--a quantitative review. Br J Cancer 2001; 85: 984.

14. Leiba A, Kark JD, Afek A, et al. Adolescent obesity and paternal country of origin predict renal cell carcinoma: a cohort study of 1.1 million 16 to 19-year-old males. J Urol 2013; 189: 25.

15. Calle EE, Rodriguez C, Walker-Thurmond K, et al. Overweight, obesity, and mortality from cancer in a prospectively studied cohort of U.S. adults. N Engl J Med 2003; 348: 1625.

16. Steffens $\mathrm{S}$, Ringe KI, Schroeer K, et al. Does overweight influence the prognosis of renal cell carcinoma? Results of a multicentre study. Int J Urol 2012; 26: 10.

17. Waalkes $\mathrm{S}$, Merseburger AS, Kramer MW, et al. Obesity is associated with improved survival in patients with organconfined clear-cell kidney cancer. Cancer Causes Control 2010; 21: 1905.

18. Choi $Y$, Park B, Jong BC, et al. Body mass index and survival in patients with renal cell carcinoma: a clinical-based cohort and meta-analysis. Int j Cancer 2013; 132: 625.

19. Klinghoffer Z, Yang B, Kapoor A, et al. Obesity and renal cell carcinoma: epidemiology, underlying mechanisms and management considerations. Expert Rev Anticancer Ther 2009; 9: 975.

20. Vansaun MN. Molecular pathways: adiponectin and leptin signaling in cancer. Clin Cancer Res 2013; 15; 19: 1926.

21. Sierra-Honigmann MR, Nath AK, Murakami C, et al. Biological action of leptin as an angiogenic factor. Science 1998; 281: 1683.

22. Cufic A, Gamulin M, Ferencic Z, et al. Environmental exposure to xenoestrogens and oestrogen related cancers: reproductive system, breast, lung, kidney, pancreas, and brain. Environ Health 2012; 11: S1-S8.

23. XuX, D Veenstra T. Concentration of endogenous estrogens and estrogen metabolites in the $\mathrm{NCl}-60$ human tumor cell lines. Genome Med 2012; 4: 31.

24. Villeda-Sandoval $\mathrm{Cl}$, Chapa-Ibargüengoitia $\mathrm{M}$, CastillejosMolina RA, et al. Subcutaneous adipose abdominal tissue is related to favorable pathological characteristics of renal cell carcinoma. J Urol 2013; 189 (Suppl 4): e302.

25. Park HY, Lee JK, Kim KM, et al. Visceral obesity in predicting oncologic outcomes of localized Renal Cell Carcinoma. J Urol 2014; 192: 1043. 